

Madoc-Jones, I, Hughes, C, Gorden, C, Dubberley, S, Washington-Dyer, K, Ahmed, A ORCID logoORCID: https://orcid.org/0000-0002-6164-0656, Lockwood, K and Wilding, M (2018) Rethinking preventing homelessness amongst prison leavers. European Journal of Probation, 10 (3). pp. 215231.

Downloaded from: https://e-space.mmu.ac.uk/625887/

Version: Accepted Version

Publisher: Sage

DOI: https://doi.org/10.1177/2066220318822245

Please cite the published version 


\title{
Rethinking preventing homelessness amongst prison leavers
}

\section{Iolo Madoc-Jones}

Wrexham Glyndwr University, UK

\section{Caroline Hughes}

Wrexham Glyndwr University, UK

\section{Caro Gorden}

Wrexham Glyndwr University, UK

\section{Sarah Dubberley}

Wrexham Glyndwr University, UK

\section{Karen Washington-Dyer}

Wrexham Glyndwr University, UK

\section{Anya Ahmed}

University of Salford, UK

\section{Kelly Lockwood}

University of Salford, UK

\section{Mark Wilding}

University of Salford, UK

\begin{abstract}
The Wales (Housing) Act 2015 introduced a preventative approach to addressing homelessness that impacted on prison leavers in Wales. Since the same changes will take effect in England from October 2018, this paper provides early insight into how
\end{abstract}

Corresponding author:

lolo Madoc-Jones, Wrexham Glyndwr University, Wrexham, LLI I 2AW, UK.

Email: i.m.jones@glyndwr.ac.uk 
new preventative duties have been implemented in Wales. Drawing on interviews with I I4 stakeholders and 75 prison leavers, we report that the promise associated with a preventative agenda is presently not fully realised. We contend that resettlement activity might be improved if it was better incentivised and facilitated inside the prison wall. However, we also suggest the time has come for more radical options to be pursued to address homelessness amongst prison leavers. We argue against short prison sentences, which are so often causative of homelessness, and for providers of probation services to be better incentivised and resourced to take a more active role in meeting accommodation needs.

\section{Keywords}

Homelessness, prevention, prison leavers, resettlement

\section{Background}

The 2010 Green Paper, Breaking the Cycle, (Ministry of Justice, 2010) heralded what was described as a new approach to tackling re-offending. It included a commitment to tackle barriers to rehabilitation and led to the publication of Transforming Rehabilitation: A Strategy for Reform (Ministry of Justice, 2013). Subsequent to this, the Offender Rehabilitation Act 2014 (ORA) introduced changes to the way offenders would be supervised in custody and in the community. From June 2014, the Ministry of Justice split the existing 35 Probation Trusts into a public sector National Probation Service (NPS) and 21 new Community Rehabilitation Companies (CRCs). The NPS responsibilities were redefined so that its staff would advise courts on sentencing and manage those offenders who present a high risk of serious harm to others (or were Multi-Agency Public Protection Arrangements (MAPPA) nominals). CRCs would supervise all other offenders who were assessed as being at low or medium risk of causing serious harm to others.

CRCs were also contracted to undertake resettlement work at prisons within their catchment areas. To facilitate such 'Through the Gate' (TTG) services, 70 of the 123 prisons in England and Wales were designated as resettlement prisons. In some of these prisons, CRCs subcontracted provision of TTG services to voluntary organisations such as Shelter. The intention was that in the last 3 months before release, prisoners would be transferred to the resettlement prison in their local area and pre-release support and supervision arrangements would be developed from that point (HMIP, 2017). Activity would be focussed on the seven pathways to Reducing Re-Offending established by the Government's Reducing Re-offending National Action Plan: substance misuse; thinking attitudes and behaviours; relationships and family; offending behaviour; finance and debt; employment, training and education; and, finally, accommodation (Home Office, 2004). In this paper, we focus on how accommodation services to adults leaving prison and facing homelessness have been developed since 2015.

Defining resettlement is not an easy task. As Raynor (2007) argues, the concept is predicated on the disputable notion that prison leavers' pre-custody experiences were of being 'settled'. For those for whom this was not the case, successful resettlement could then amount to no more than being returned to an environment that is more supportive of 
further offending than desistance. Measures such as helping prison leavers find employment and accommodation seem to be important in the desistance process. However, the precise relationship with these circumstantial factors and desistance is unclear so that whilst they are considered necessary for desistance to take place, they may not be sufficient for that purpose. Be that as it may, in 2002 the Social Exclusion Unit suggested housing prisoners could reduce reoffending by $20 \%$ (SEU, 2002). People who have accommodation arranged on release are four times more likely to have employment, education and training arranged than those who do not (Niven and Stewart, 2005). In the Surveying Prisoner Crime Reduction study of 2012, more than three-quarters of prisoners $(79 \%)$ who reported being homeless before custody were reconvicted in the first year after release, compared with about half (47\%) of those who did not report being homeless before custody (Ministry of Justice, 2012).

Prior to ORA, prisons did not have an evidently good track record in helping prison leavers avoid homelessness. A survey of 680 prisoners in 2010 found that only $21 \%$ reported being aware of any housing provision in their prison and only $4 \%$ had engaged with such provision (Gojkovic et al., 2012). In 2010, The Howard League reported that one third of people leaving prison had nowhere to go (Howard League, 2013). In 2014, Crisis reported that $41 \%$ of the 480 single homeless people they interviewed had served a prison sentence at some point (Crisis, 2014).

One reason for this may have been that prior to the ORA 2014, prisoners sentenced to under 12 months in custody were not eligible for any assertive post-release supervision. The majority of sentenced prisoners serve under 12 months in custody. In the 12 months ending March 2015, for example, 51,686 (57\%) prisoners were serving 6 months or less, and a further $6055(7 \%)$ were serving more than 6 months but less than 12 months (Ministry of Justice, 2015). ORA 2014, however, extended post release supervision to all those serving sentences of over 1 day. It thereby increased by an estimated 45,000 offenders per year, the numbers of prison leavers eligible for post release supervision (House of Commons, 2016).

It might be expected that the situation would be improved subsequent to ORA. This is especially so given changes to the way homelessness is dealt with in England and Wales following on from the Wales (Housing) Act 2015 and, in England, the Homelessness Reduction Act 2015. Both Acts heralded a more preventative and person-focussed approach to addressing homelessness. They placed new duties on local authorities to take reasonable steps to help to prevent or help to secure accommodation in all cases where a person/household is threatened with, or find themselves homelessness. Reasonable steps could involve the local authority helping an applicant find private rented accommodation and/or acting as guarantor and could extend beyond helping an individual or family to find shelter to address issues that might cause homelessness; for example, substance misuse or budgeting difficulties. In the majority of cases local authority assistance should be provided for 56 days and, unlike the situation prior to the Act, the assistance is largely unconditional and available to all applicants.

In Wales, the practical implications of the Act as far as prison leavers are concerned were negotiated between the Welsh Government, Local Authorities, NOMS and CRCs and enshrined in 'The National Pathway for Providing Services to Children, Young People and Adults in the Secure Estate' (Welsh Government, 2015). Thereafter, TTG 
resettlement staff in prisons, local authority housing staff and staff providing probation services were expected to work together in the 56 days before a prisoner is released to meet their housing, rehabilitation and resettlement needs. Such multi-agency working has been associated with practice improvements in some areas such as tackling antisocial behaviour and youth offending (Hobson et al., 2018), managing offenders at high risk of causing serious harm to others. That said, partnership working in the criminal justice system has traditionally come at a cost, in particular where police and probation agendas can come to dominate (Harvie and Manzi, 2011).

\section{A process and outcome evaluation of a UK youth intervention}

The relevant sections of the Homelessness Reduction Act did not come into force in England until October 2018, but in Wales the Wales (Housing Act) has been operational since April 2015. So, this paper explores the experiences of prison leavers in Wales and thereby provides early insight into practice in that context and how the legislation might come to affect practice in England. The findings will be of interest more broadly in countries considering the advantages of outsourcing aspects of offender management and wishing to develop and expand on preventative provision for homeless prison leavers.

\section{Methodology}

This paper draws on data gathered as part of a Welsh Government funded evaluation for the National Pathway for providing service to adults leaving the secure estate in Wales. The study was approved by the National Research Council, by the National Probation Service (Wales), Working Links (CRC in Wales); Purple Futures (CRC in North West England), the Governors of the prison establishments involved in the research study and Wrexham Glyndŵr University's Research Ethics Committee. The study drew on responses to a survey from a representative from each of the 22 local authority housing options teams in Wales and interviews with representatives from five respondent groups. These were local authority staff $(n=21)$; prison-based staff $(n=19)$; community-based housing/housing support staff $(\mathrm{n}=18)$; and Responsible Officers, that is, staff from probation services supervising prison leavers on release $(n=34)$. Collectively here at times, they are identified as stakeholders in the process of housing prison leavers. The research also involved interviewing prison leavers themselves and attempts were made to interview them twice. The first time (wave 1) 4-6 weeks before they were released $(n=75)$ and the second time (Wave 2) 6-8 weeks after release $(n=22)$. The study therefore involved a large number of respondents $(\mathrm{N}=189)$ and interviews $(\mathrm{n}=211)$.

Prisoners were sampled from five different prisons so that the research engaged with the experiences of those serving under 12 months in custody (two male cat B local resettlement prisons), over 12 months in custody (three cat $\mathrm{C}$ resettlement prison), inclusive of prisons serving male (three prisons) and female populations (two prisons). Gatekeepers were provided with information sheets to give to and use to recruit, potential respondents. These were distributed by TTG staff to prison leavers receiving a service from them and who were due to be released in the 4-6 week window following on from the days when it was agreed research staff would be attending the prison. Thereafter, willingness 
to participate in the research was re-established on the day of the interview. A small but unknown number of prisoners declined to engage but those willing $(n=75)$ were interviewed face to face.

Of the wave 1 respondents, 67 agreed to participate in a follow up interview 6-8 weeks after release. To facilitate this, the research team were provided with details about these prison leavers' responsible officer by the NPS and CRC. Subsequent efforts in their regard led to 22 wave 2 /follow on interviews at the probation office to which the prison leaver was reporting. Where three attempts to engage responsible officers produced no response (15); the prison leaver had moved out of Wales (5); prison leavers had been gate-arrested, re-arrested/breached and retuned to custody (19); or failed to attend two appointments with researchers (6), follow up interviews were not pursued further.

Prison leavers were only interviewed if they were judged as having the capacity to consent and agreed to take part in the study. This was assessed at each stage of the recruitment process (pre-engagement by gatekeepers and pre-interview by researchers). Some limits were intended to apply in relation to confidentiality and anonymity. These were identified in the information sheets given to potential respondents and on consent forms.

Professional staff and stakeholders were sampled through existing contacts in the criminal justice and housing fields. Here, a mixture of telephone and face to face interviews were carried out.

Researchers made clear that all respondents were free to decide what information they wished to share with the researcher and that they should feel under no pressure or obligation to discuss matters that they did not wish to. When interviewing, researchers followed a Managing Distress and Managing Disclosures Policy. All interviews were recorded and transcribed verbatim.

The approach to data analysis for this paper involved members of the research team re-reading interview transcripts to specifically identify how homelessness was being addressed as a prison leaver approached release. As the data was analysed, researchers sought to keep in mind that the criminal justice system is adversarial and one purpose served by interview accounts is to convey narrators' preferred self-images (Blaxter, 1997). Accordingly, in presenting the data, the focus is on the broad picture and findings that capture consistencies both within and between respondent accounts. To protect respondents' anonymity, findings are presented using data extracts codes. Prison leaver respondents are coded PL1-PL75; local authority stakeholders are coded LA1-LA21; prison-based staff are coded PB1-19; community-based staff are coded CB1-CB18; Responsible Officers are coded RO1-RO34.

\section{Findings}

\section{Housing referrals}

In Wales, it had been agreed at the strategic level by NPS, CRC and local authority staff that the process of addressing homelessness amongst prison leavers would begin with staff in the prison sending a referral about a prisoner who is likely to be homeless on release to the prison leaver's home local authority area. The referral would be sent 66 
days before a prisoner is released (to ensure enough time for the prison leaver to benefit from the full 56 days of preventative activity) and contain enough details for local authority staff to negotiate with the prison leaver and relevant parties as to what help would be most appropriate.

Conversely, stakeholders considered that housing referrals were mostly not submitted or if they were, they were usually submitted late giving them insufficient time to engage with prison leavers prior to release. This tendency was described as particularly acute in relation to referrals from prisons dealing with a large number of reception and resettlement cases. The following accounts from stakeholders are representative of how the process for receiving referrals was perceived by professional stakeholders who were party to the process:

We don't get referrals, we sometimes get the names of who is coming out from probation contacts but that's it. Nothing seems to be happening in prison at the moment which is a shame we used to have good links with the staff in there (LA4).

We're not getting them. I don't know why and whether it's a policy thing but if we get to hear someone is coming out it's rare and we normally find out when they turn up at our office. (LA11)

Stakeholders indicated that most prison leavers would not be seen by TTG staff until 1-6 weeks of release and that only in some instances would a referral be forthcoming at that point. Where referrals were received the quality of information in them was assessed as poor. This was linked to a number of factors, the first being that some were completed by the prison leaver themselves or by one of their peers in prison.

One of my big complaints is the referral we end up with is quite often completed by the client so we are not getting the information we need ... They are given the referral form but they fill it in themselves which means we don't get the information that we need, we can't access the prisoners, we set up interviews, it's not possible, we can't speak to them, we just can't get the information we need to be able to help. (LA7)

Stakeholders were critical of practices that involved prisoners completing referrals for themselves or for other prisoners. Here, their concerns related to the accuracy of the history that would be provided and the housing preferences that would be identified:

Everyone wants a two bedroomed flat overlooking xxx but we just don't have those options available and even if we did, many people couldn't just be dropped into that situation. It's just not useful to say that and it gives us nothing to go on in terms of helping someone. (LA 20)

A second reason stakeholders suggested that the quality of housing referrals could be poor was that up to date information about a prisoner might not be accessed or shared to help inform housing decisions. Accessing relevant information was clearly not possible in cases where housing referrals were completed by peers. However, not one TTG staff member responsible for housing referrals suggested that they routinely accessed exiting assessments for the purposes of making housing referrals either. In some cases, TTG did 
not have access to the relevant databases. Accordingly, in most cases, referrals were based only on what the prison leaver told the referring peer or TTG officer:

Referrals are either not received or when they are, they are received within just a few days of release and the information is not detailed enough to make any decisions, and often not even enough to undertake substantive further enquiries. (LA18)

Accounts of poor referral practices focussed on TTG staff being too few in number and under incentivised to engage fully with agreed referrals processes. Challenges were associated with managing the 'churn' of people in and out of the larger prisons so that a bureaucratic and administrative approach to practice had come to prevail:

If I'm honest I think, there's not enough workers to do everything. I think when the CRC came in, not everyone was being supervised by CRC, I don't think there was any new staff so there is all this extra workload there isn't enough bodies on the ground to do all the work that needs to be done. (PB6)

They're all a bit deflated and run ragged, it's enough for most of them just to get on the wings and get the basics done let alone have a meaningful and productive conversation with anyone. (LA7)

TTG staff were largely aware that they were going through the motions as far as housing referrals were concerned. Whilst many wanted to do more, delivery contracts merely required that referrals were completed and mechanisms did not exist to monitor and provide feedback on the quality of the work undertaken:

It's a practical thing, all that's required is a referral has to be done so it's a case of having a quick chat and making sure the basics, name, previous housing history and things like vulnerabilities are covered and that's that box ticked. (PB2)

\section{Partnership working and prioritisation}

The Housing (Wales) Act 2015 was intended to change the relationship between local authorities, prison and probation staff and people who are facing homelessness in custody by promoting a partnership approach to addressing needs that would be enshrined in a Personal Housing Plan for each person. Practical difficulties engaging with prisons and prisoners, however, made such a philosophy difficult to adopt. For the most part, local authority housing staff perceived that liaising with TTG or CRC staff, arranging to come to visit prison leavers or having online or telephone conversations with them was all but impossible:

We can't get the contact of the prisoner to discuss the property to be able to pass on, our idea was we would use the resettlement officer to bounce through photos of the properties so they can have a look but there's no response there. The resettlement team quite often can't get on the wing, they will make appointments and I will phone and say 'what happened?' and they would say 'we couldn't get on the wing today', information just doesn't flow in and out. (LA21) 
Conversely, prison staff considered that the needs of prison leavers could sometimes be ascribed a lower priority by local authority housing staff. As the following extract illustrates, it was considered that housing staff were often faced with multiple demands on their time and in terms of prioritisation 'presence' and perceptions of who deserved help might be relevant considerations:

Quite frankly, if they're dealing with a woman fleeing domestic violence, who is sat in front of them or someone coming out of hospital or homeless in the community who hasn't offended, I don't suspect they're facing much of a choice of where they put their energy. (PB14)

Low expectations around local authority prevention activities were expressed by TTG staff. At one prison, in response to a statement by a Prison Leaver during an interview that they had not heard back from housing, a TTG staff member commented:

I think I have had something through for you actually, I think it's in the office in an envelope, your personal housing plan, it doesn't really tell you anything ... but I've got that in the office but I will send it down to you, I'll drop it on the wing to you this afternoon. (PB 11)

Prison based stakeholders suggested PHPs were infrequently completed and those that were done were generic and formulaic:

The reasonable steps requirements for some Local Authorities it just seems like they are cutting and pasting when we see the letters it just seems nothing is being done specifically for the needs of that person and it's just becoming a box ticking exercise. (PB 1)

I don't like the letters.... it's very standard other than just changing the name at the top of the letter saying that an application has been done. (PB11)

At times, a certain fatalism seemed to permeate local authority staff accounts of working with prison leavers. Prison leavers were understood as hard to place as a function of negative attitudes towards them, and changes to welfare law that had reduced the incentive for private rented and social housing providers to house anyone who was young and unemployed, let alone a prison leaver:

No one's going to house a prison leaver, not without meeting them and if we tell them about them, give them the whole picture they are not going to house them, and you can't blame them, why would anyone when there's more demand than supply and plenty of other people you might take? (LA 10)

\section{Short term/revolving door prisoners}

A preventative approach was especially difficult to adopt where individuals were sentenced to fewer than 4 months in custody and so immediately entered the 66/56 day resettlement window on arrival at the prison. Short term prisoners were often individuals who were chaotic and difficult to engage and who had a long history of street homelessness. Often with multiple failed tenancies, problems with mental health and substance misuse they found themselves in custody for having histories of failing to 


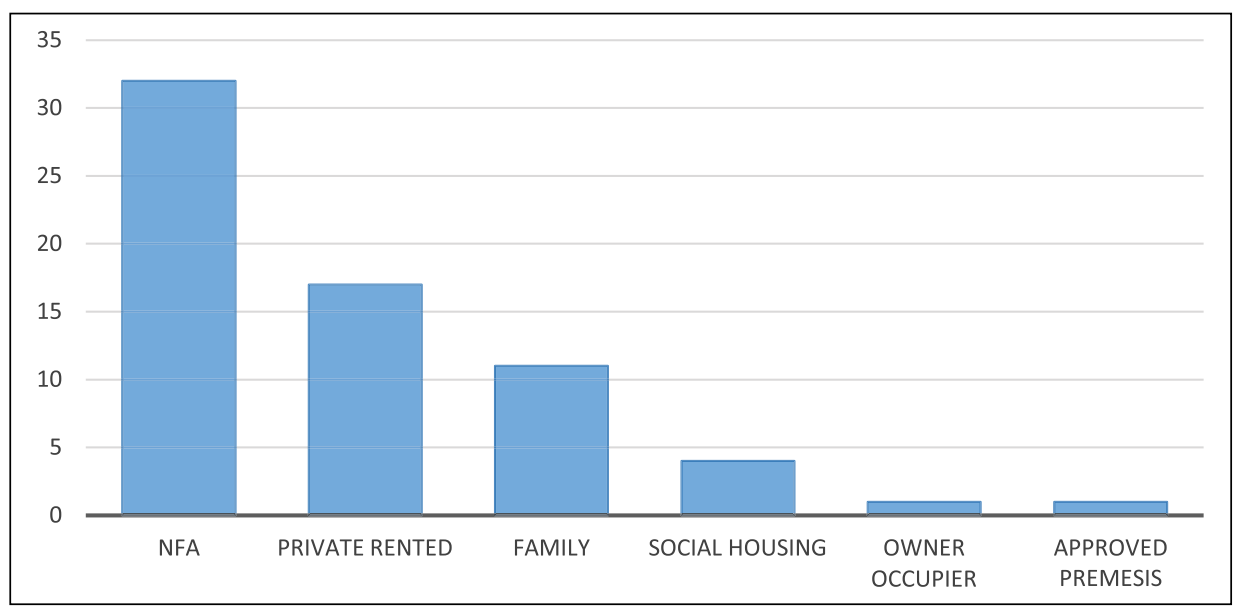

Figure I. Accommodation status of 66 prison leaver respondents on reception into custody.

comply with community penalties. They were engaged in petty, nuisance type offending and caught in a revolving door of often being in custody for a few weeks, being released homeless only to reoffend again in some relatively small way and finding themselves back in custody.

Some people are in and out, they might go back in for 2 weeks and then they're out again. ... The people that tend to be on that revolving door . . . so it tends to be 14 days back in custody and then ... back to square one every single time. (RO17)

The problem is, until she gets stable accommodation and stable address, services can't work with her and she can't get a stable address because she doesn't comply and work with services, it's like, stuck between a rock and a hard place. (RO24)

\section{Prison leaver respondents}

As previously stated, 75 prison leavers were interviewed in custody (wave 1), 67 of whom were due for release. Sixty-six respondents told us what their accommodation status was at the point they were imprisoned. As the Figure 1 below illustrates, homelessness and imprisonment show some linkages. A large percentage were homeless and many of those who were not homeless had experience of unstable accommodation in the months leading up to their imprisonment.

Many of those who were not homeless talked of losing accommodation by dint of being imprisoned. Fifty-nine respondents were engaged in discussions about their release plans. Of these, 34 prison leaver respondents reported expectancies around being of no fixed abode (NFA). Only seven referred to some ongoing activity (above and beyond the housing referral being submitted) associated with attempts to make accommodation available to them. Of significant concern was that so few respondents could provide a concrete release address. As well as the 34 who anticipated being NFA, five of the 13 
prison leaver respondents intending to return to family referred to their intentions still being subject to approval by providers of probation services. Of note is that some of these prison leavers had been in custody for quite some time. Yet they still faced the prospect of being homeless on release.

Prison leaver respondents linked homelessness to offending and reoffending. Almost all of those who anticipated being NFA, anticipated being back in custody soon. Some talked of (re)offending on purpose to avoid the possibility of being on the street:

If there is absolutely nothing, there is no way I am staying on the streets, I'll just do something to come back here, that's all it is just back and forward. (PL42)

I'm in every year to tell you the truth ... I'm on the street like three months and I need a break so I come here, I do things on purpose, it's getting worse on the streets, my health goes down, my drug habit goes up I'm sick of this so I'll just get nicked, just to get out for a bit. (PL37)

Prison leaver respondents were critical of practices that involved their peers completing housing referrals on their behalf. Here, their concerns related to the potential negative ramifications of disclosing personal details:

It was a prisoner that came around and did it, it wasn't like it was their job in prison but it wasn't like official so I don't know if I would feel comfortable really discussing it with them anyway. (PL26)

He was just an inmate; I would imagine he was a peer advisor. The only trouble I had with that was basically he handed it to me and walked away. He said he'd be back to check it over, but I didn't know this guy. (PL34)

Yet they were systemically poorly placed to offset the lack of effort to address their accommodation needs by making their own efforts before they were released. Prison leavers perceived that they were still treated as 'risky' in prison even though they would be released in a matter of days or weeks. So, they were not allowed access to the means to find their own housing or make their own contact with local authorities or housing providers; for example, access to newspapers, internet and telephone. Prison leaver respondents described the experience of approaching release without a fixed address as anxiety provoking and stressful. Very few did not provide an account of their state of mind during wave 1 interviews in custody that did not resemble the following example:

Well someone was meant to come and let me know what's going on with the form I filled in but like I said no one has come back to me and let me know what's going on yet ... nine times out of 10 I break down into tears because, I don't know, its fear of the unknown and that's a big thing with anxiety. (PL18)

At wave 2, 67 prison leaver respondents could still potentially be followed up. Attempts to do this, established the following destinations shown in Figure 2.

A seemingly large number of prison leaver respondents had been returned to custody $(n=17)$. It was not possible to re-interview these individuals and so accordingly it is not possible to comment on the role their accommodation status had to play in this outcome. 


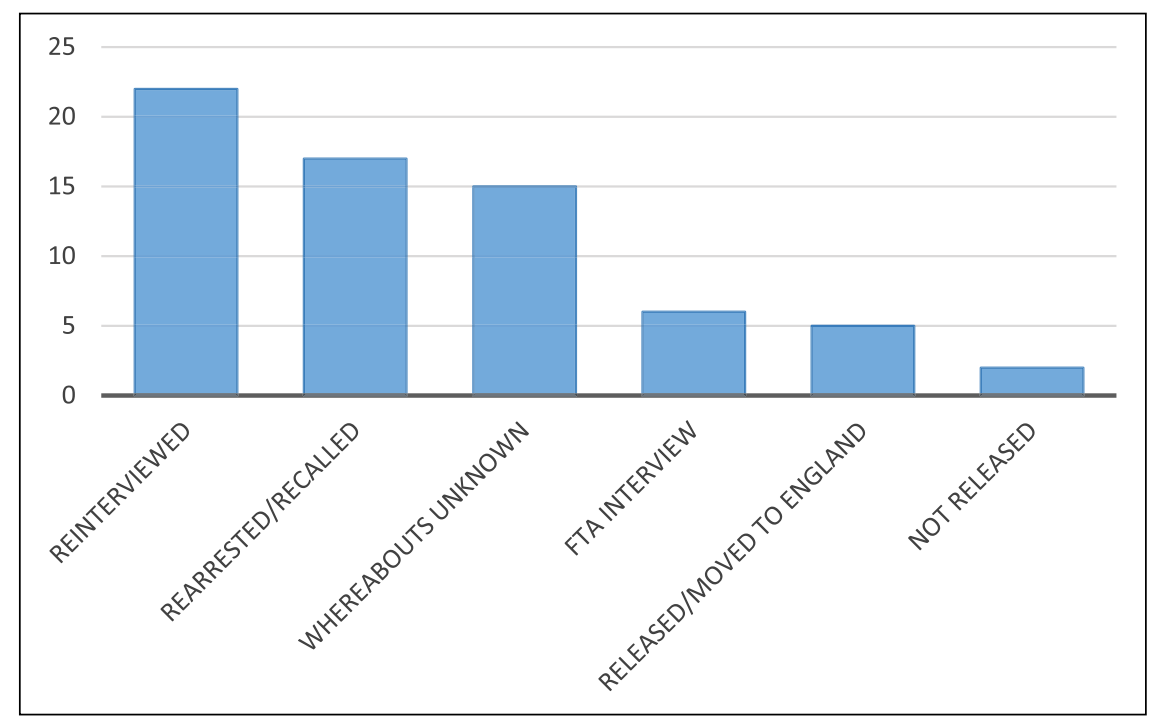

Figure 2. Prison leavers' status at Wave 2 follow up.

Base: 67 Prison leavers eligible for follow up and wave 2 interviews.

However, 15 of those recalled had discussed their accommodation plans with researchers at wave 1 and of these, nine had anticipated being NFA. Of concern is the amount of prison leavers whose whereabouts were unknown. That is to say, their accommodation status could not be clarified with any certainty giving rise to the possibility this was associated itself with homelessness in one of its many forms.

Twenty-two prison leaver respondents were re-interviewed. Eight were NPS cases and 14 were CRC cases. During interviews they reported their accommodation status at that point as shown in Figure 3.

A little over a quarter of the prison leavers interviewed $(n=6)$ at wave two were homeless. Of the 22 prison leaver respondents who were interviewed, 15 referred to having some contact with and help from the local authority housing team after they were released from custody. Nine of the prison leaver respondents said a housing organisation/helping agency had also become involved with them and helped them find accommodation. The picture here therefore was mixed. Some prison leavers who maintained contact with agencies were helped into accommodation. Some, however, remained street homeless notwithstanding engagement with professionals who might have helped them.

\section{Discussion}

It would be a matter of some regret were our paper to be understood as castigating individual TTG or local authority staff or suggesting we did not encounter any examples of accommodation needs being assessed thoughtfully. Conversely, we intend our paper to encourage reflexivity about the systematic level challenges associated with implementing a preventative approach to managing homelessness amongst prison leavers. In that 




Figure 3. Accommodation status of prison leaver respondents $(n=2)$ interviews at wave 2 in the community.

Base: Self report by 22 prison leavers interviewed at wave 2 .

regard, it is worth noting that as critical as stakeholders could be about practices to addressing homelessness under the prevention agenda, most evaluated the development as a step in the right direction. This understanding seemed to derive from a perception that 'in principle' the approach provided access to services for prison leavers. However, the commitment and capacity of some organisations and staff to move beyond a procedural and administrative approach to practice and to engage more assertively with prison leavers to help them secure accommodation was clearly limited. This was linked by respondents to resource limitations inside the prison wall; the impermeable nature of prisons; a lower priority being ascribed to prison leavers; the use made of short prison sentences; and the lack of housing options available for prison leavers.

One need is to assess the level of resources directed at TTG work when CRC contracts are reviewed, earlier than intended, in 2020. The use of peers to assess the needs of prison leavers presents as suboptimal. This is because guiding and directing prison leavers towards appreciating their best housing options is a significant and challenging task especially where the additional support needed to maintain a tenancy and the urgency of any need has to be assessed and then negotiated with a local authority. If, as suggested, the needs of prison leavers may at times be afforded a lower priority, the ability to advocate on their behalf is crucial. The ability to advocate on behalf of prison leavers may be very relevant in the field of homelessness where neither the definition of homelessness, need, 'reasonable steps' or vulnerability (and priority need status) are very clearly defined. For example, the test commonly used to establish if someone was 'vulnerable' and, therefore, eligible for temporary accommodation has become known as the Pereira test. The Court of Appeal, in Pereira v Camden Council, held that a person is vulnerable if their circumstances are such that they would suffer more when homeless than 'the 
ordinary homeless person'. Priority need status and temporary accommodation may follow on from being designated as 'vulnerable as a result of custody'. However, homeless prisoners may be poorly placed to advocate this point, or any other, on their own behalf.

Preventative work depends on partnership working in the last 3 months of a prison leaver's sentence and this requires prison walls to be far more permeable than such institutions in England and Wales have tended to be. In a number of European contexts, conjugal visits are facilitated, access to the internet is allowed, and prisoners have greater freedom to make and receive visits through the prison walls as they approach their release dates (De Claire and Dixon, 2015; Knight, 2015). Here, the designation of 70 of England and Wales' 123 prisons as 'resettlement prisons' is problematic. If over half of all prisons in England and Wales are 'resettlement prisons' and this includes various types of establishments, then what it means to be in such a prison and in the 'resettlement phase' of one's sentence becomes hard to standardise. Traditionally, long-term prisoners have moved through the prison system and eventually to Cat D 'open' prisons where, in light of the fact they would be released soon in any case, greater freedom and contact with home communities has been the norm. In the context that prison leavers are currently dispersed in different types of resettlement prisons, the possibility that such greater freedoms may be enjoyed by all prisons leavers is low. However, relaxing constraints on visits, allowing greater access to phone and internet resources, making release on temporary licence more common, adopting different regimes on designated resettlement wings and even facilitating early release to designated 'half way' homes are options that need to be considerate as part of a package of activities to make prison walls more permeable and preventative activities around homelessness possible.

In relation to the prioritisation of prison leavers, it is apposite to note that professional practices take place within a wider ideological context. Carlen (1998) argues that dominant political and populist ideologies on crime currently structure penal policy and practice around a punitive 'risk crazed governance' wherein the offending 'other' is extracted from their social context, largely perceived as the author of their own circumstances and responsible for changing themselves. In that context, it would be surprising to find that prison leavers are naturally afforded equal priority for social welfare as others. Popular punitiveness is not evidently on its way out, but subversion of the exclusionary narratives may be promoted by reflective practice amongst those working with prison leavers, discussion about institutional values and moralities and the social circumstances that can give rise to anti-social behaviour, offending behaviour and homelessness.

Dominant political and populist ideologies on crime underpin mass imprisonment and the use of short-term sentences. Yet counter to this, it is largely accepted that homelessness may promote offending and reoffending, and prison sentences, especially short ones, can trap people in a vicious cycle of minor offending followed by stigmatisation, homelessness and more offending. Hitherto, the solution to this has taken the form of bolting onto a system that creates harm, a process for undoing that harm. In the absence of evidence that such an approach can work, however, it is increasingly likely that the advantages of not inflicting the harm in the first place will be identified. So, unsurprising to note that in May 2018 the Justice Minister in England and Wales, added his voice to that of others calling for sentences of under 12 months in custody to be 'the last resort' 
(Gayle, 2018). Our findings provide additional mandate for a radical rethink of the purpose and use made of imprisonment and especially short-term sentences that in our research was often experienced as neither punitive nor rehabilitative but, instead, associated with homelessness and crime.

The context for CRCs taking over accommodation related activity could hardly be more challenging as over the last 10 years a perfect storm of events has engulfed and worsened the accommodation prospects of this group of people. Stephens and Stephenson (2016) argue that house building has slowed down and house prices have increased significantly. Home ownership has been in decline as first-time buyers have found themselves priced out of the market. Thus, in England the proportion of 25- to 34-year-olds renting privately has increased significantly over 10 years from $2 \%$ in 2005-2006 to $46 \%$ in 2015-2016 (Hodgson, 2017). Linked to this, the Welfare Reform and Work Act 2012 (WRWA) introduced the so called 'Bedroom Tax', which meant that welfare claimants had their housing benefit reduced by $14 \%$ if they had one spare room and $25 \%$ if they had two or more. As a result of both these developments, the supply of one/two bedroomed rental properties, traditionally occupied by prison leavers, has significantly atrophied.

Prison leavers have always had to overcome the stigma of their imprisonment when seeking housing (Moore et al., 2016). The reluctance to house prison leavers, however, seems likely to have increased since 2012 (Crisis, 2016). This is because historically the rental income of those claiming state benefits, as prison leavers tend to have to do initially, usually derived from Housing Benefit payments and was paid directly to landlords. The introduction of Universal Credit under the WRWA, however, has associated with all claimants, including prison leavers, receiving all their benefits directly as one single payment increasing the likelihood that those who have difficulty budgeting or who might use their money on substance misuse will fail to pay rent. The WRWA 2012 also introduced a policy of a freezing housing benefit payments for four years starting 2016/2017. Further dis-incentivising landlords from offering accommodation to prison leavers, Single Accommodation Rates (SAR) were introduced in 1996 (Cooper, 2016). By now, this limits the Housing Benefit allowance for a person under the age of 35, which prison leavers tend to be, to the average for a single person in shared accommodation in any particular local authority area.

At the same time therefore, as preventative policies are being introduced to address homelessness in general, policies are also being enacted that inevitably make housing prison leavers who are homeless more difficult. The contradiction and lack of joined-upness here is clearly startling and the solution not straightforward. The absence of suitable accommodation for prison leavers to occupy represents a very significant challenge to a preventative agenda. Put simply, even if processes and practices could be made to work well, without a sufficient supply of properties for prison leavers to occupy, a preventative agenda is meaningless. At present, prison leavers are so dis-preferred as tenants and demand for suitable property so high, more social housing specifically for this group is needed. Here, providers of probation services could consider how they might provide accommodation and support to all prison leavers, in the same way that they currently provide it in approved premises or probation hostels to prison leavers assessed as dangerous. 
Qualitative research is associated with some fairly obvious limitations that preclude any simple generalization of the findings. However, this was a large-scale project and there were consistencies within and between many respondent accounts and emerging themes seemed supported by aspects of the existing literature. Additional limitations of the paper relate to the inability to follow up most prison leavers in the community and the use of gatekeepers in recruiting prison leavers before and after they were released from custody.

Our research identifies problems with adopting a preventative agenda with prison leavers. Resource limitations inside the prison wall; the impermeable nature of prisons; a lower priority being ascribed to prison leavers; the use made of short prison sentences and a lack of housing options render the promise associated with a preventative agenda unrealised. We contend that resettlement activity might be improved if it was better incentivised and facilitated inside the prison wall. However, we also suggest the time has come for more radical options to be pursued to address homelessness amongst prison leavers. We argue for short prisons sentences, which as so often causative of homelessness amongst prison leavers, to be abolished and for providers of probation services to be better incentivised and resourced to take a more active role in meeting accommodation needs.

\section{Funding}

This research received no specific grant from any funding agency in the public, commercial, or not-for-profit sectors.

\section{References}

Blaxter M (1997) 'Whose fault is it? People's own conceptions of the reasons for health inequalities. Social Science and Medicine 44: 747-756.

Carlen P (1998) Imaginary Penalities. London: Routledge.

Cooper V (2016) 'It's all considered to be unacceptable behaviour': Criminal justice practitioners' experience of statutory housing duty for (ex) offenders. Probation Journal 63(4): 433-445.

Crisis (2014) Nations apart? Experiences of single homeless people across Great Britain. Available at: https://www.crisis.org.uk/ending-homelessness/homelessness-knowledge-hub /types-of-homelessness/nations-apart-experiences-of-single-homeless-people-across-great -britain-2014/ (accessed 21 June 2018).

De Claire K and Dixon L (2015) The effects of prison visits from family members on prisoners' well-being, prison rule breaking, and recidivism. A Review of Research Since 1991. Trauma, violence, \& Abuse 18(2): 185-199.

Gayle D (2018) Short prison sentences do not work, says justice secretary. Guardian, 26 May. Available at: https://www.theguardian.com/society/2018/may/26/short-prison-sentences-do -not-work-says-justice-secretary-david-gauke (last accessed 18 December 2018).

Gojkovic D, Mills A and Meek R (2012) Accommodation for ex-offenders: Third sector housing advice and provision. Third Sector Research Centre. Working Paper 77. Available at: http:// www.birmingham.ac.uk/generic/tsrc/documents/tsrc/working-papers/working-paper-77.pdf (accessed 1 September 2018).

Harvie P and Manzi T (2011) Interpreting multi-agency partnerships: Ideology, discourse and domestic violence. Social and Legal Studies 20(1): 79-95. 
Hobson J, Lynch K, Payne B and Ellis E (2018) Are police-led social crime prevention initiatives effective? A process and outcome evaluation of a UK youth intervention. International Criminal Justice Review. DOI: 1057567718814891

Hodgson Lord (2017) Britain's Demographic Challenge: The Implications of the UK's Rapidly Increasing Population. London: Civitas.

House of Commons (2016) Transforming rehabilitation. Committee of Public Accounts Seventeenth Report of Session 2016-17. Available at: https:/www.publications.parliament .uk/pa/cm201617/cmselect/cmpubacc/484/484.pdf (accessed 21 June 2018).

Howard League (2013) Nowhere to go: The implications for homeless people in the criminal justice system. Available at: https://howardleague.org/wp-content/uploads/2016/04/no-fixed -abode_web.pdf (accessed 1/9/18).

Home Office (2004) Reducing Reoffending: National Action Plan. London: Home Office.

HMIP (2017) An Inspection of Through the Gate Resettlement Services for Prisoners Serving 12 Months or More. London: Her Majesty's Inspectorate of Probation.

Knight V (2015) Some observations on the digital landscape of prisons today. Prison Service Journal 220(July): 3-10.

Ministry of Justice (2010) Breaking the Cycle: Effective Punishment, Rehabilitation and Sentencing of Offenders. London: Ministry of Justice.

Ministry of Justice (2012) Accommodation, Homelessness and Reoffending of Prisoners: Results from the Surveying Prisoner Crime Reduction (SPCR) survey by Kim Williams, Jennifer Poyser and Kathryn Hopkins. London: Ministry of Justice.

Ministry of Justice (2013) Transforming Rehabilitation: A Strategy for Reform. London: Ministry of Justice.

Ministry of Justice (2015) Criminal Justice System Statistics Quarterly update to March 2015, England and Wales. London: Ministry of Justice.

Moore KE, Stuewig JB and Tangney J (2016) The effect of stigma on criminal offenders' functioning: A longitudinal mediational model. Deviant Behaviour 37(2): 196-218.

Niven S and Stewart D (2005) Resettlement Outcomes on Release from Prison. Home Office Research Findings 248. Home Office: London.

Raynor P (2007) Theoretical perspectives on resettlement: What it is and how it might work. In: Hucklesby A and Hagley-Dickinson L (eds) Prisoner Resettlement: Policy and Practice. Cullompton: Willan, pp. 26-42.

Social Exclusion Unit (SEU) (2002) Reducing Reoffending by Ex-prisoners: Summary of the Social Exclusion Unit Report. London: SEU.

Stephens M and Stephenson A (2016) Housing policy in the austerity age and beyond. In: Fenger M, Hudson J and Needham C (eds) Social Policy Review 28. Analysis and Debate in Social Policy. Bristol: Policy Press, pp. 63-85.

Welsh Government (2015) The national pathway for providing services to children, young people and adults in the secure estate. Cardiff: Welsh Government. Available at: https://gov .wales/topics/housing-and-regeneration/services-and-support/homelessness/national -pathway/?lang=en (accessed 5 September 2018)

\section{Author biographies}

lolo Madoc-Jones is a professor of Criminal and Social Justice at Wrexham Glyndwr University, UK. He has a professional and academic background in probation and criminal justice. He was previously employed as a Probation Officer/Senior Probation Officer and a fee paid inspector for HMI Probation and HMI Prisons, in the latter capacity making a contribution to the inspection of resettlement provision at prisons across England and Wales. [Email: i.m.jones@glyndwr.ac.uk] 
Caroline Hughes is associate dean and senior lecturer in Criminology and Criminal Justice at Wrexham Glyndwr University, UK. Caroline has a professional and academic background in criminal and youth justice. She has been involved in a number of research projects including Wellbeing among Children and Young People in Wales and Children and Young People at Risk of or Abused through Child Sexual Exploitation in North Wales. [Email: c.hughes@glyndwr.ac.uk]

Caro Gorden is senior lecturer in Criminology and Criminal Justice at Wrexham Glyndwr University, UK. Caro has worked on the Thames Valley Sex Offender Group Work Programme and a homeless shelter for women. She has researched and published in the area of internet sex offending, drugs, prescription drug misuse, and transgender issues. [Email: C.Gorden@glyndwr .ac.uk]

Sarah Dubberley is senior lecturer in Criminology and Criminal Justice at Wrexham Glyndwr University, UK. Sarah began her career within the Youth Justice arena and her continued academic interest is within the field of Youth Justice, Homelessness and Imprisonment. [Email: s.dubberley @glyndwr.ac.uk]

Karen Washington-Dyer is senior lecturer in Criminology and Criminal justice at Wrexham Glyndwr University, UK. Karen began her career within the Youth service arena. She was coordinator for Wrexham council, ensuring youth provision was being delivered appropriately throughout the borough. [Email: k.washington-dyer@glyndwr.ac.uk]

Anya Ahmed is a professor of Social Science and Head of Social Policy at the University of Salford, UK. Prior to becoming an academic, Anya was employed by a local authority and housing association in policy and housing management roles. Anya has led a range of externally funded projects focusing on the needs and experiences of less heard communities and older people. Most recently, she had led a post-implementation evaluation of the Wales (2014) homelessness legislation. [Email: A.Ahmed@Salford.ac.uk]

Kelly Lockwood is a senior lecturer in Criminology at the University of Salford, UK. Kelly has previously worked as a manager for a women's centre working in partnership with criminal justice agencies to support women who had offended or were at risk of offending. Kelly has research interests in women and the criminal justice system and has worked on a number of externally funded research projects with a focus on mothering and imprisonment. [Email: K.A.Lockwood (a)Salford.ac.uk]

Mark Wilding is reader in Social and Public Policy at the University of Salford, UK. Mark has published extensively and has experience of researching a wide range of policy areas including employment, housing, social care, and social enterprise, among others. [Email: M.A.Wilding @.Salford.ac.uk] 